\title{
SEMI-ANNUAL REPORT ON THE PROJECT TO DESIGN AND EXPERIMENTALLY TEST AN IMPROVED GEOTHERMAL DRILL BIT, PHASE II
}

[ERDA Contract No. E(10-1)1546]

\section{By}

L. M. Barker

S. J. Green

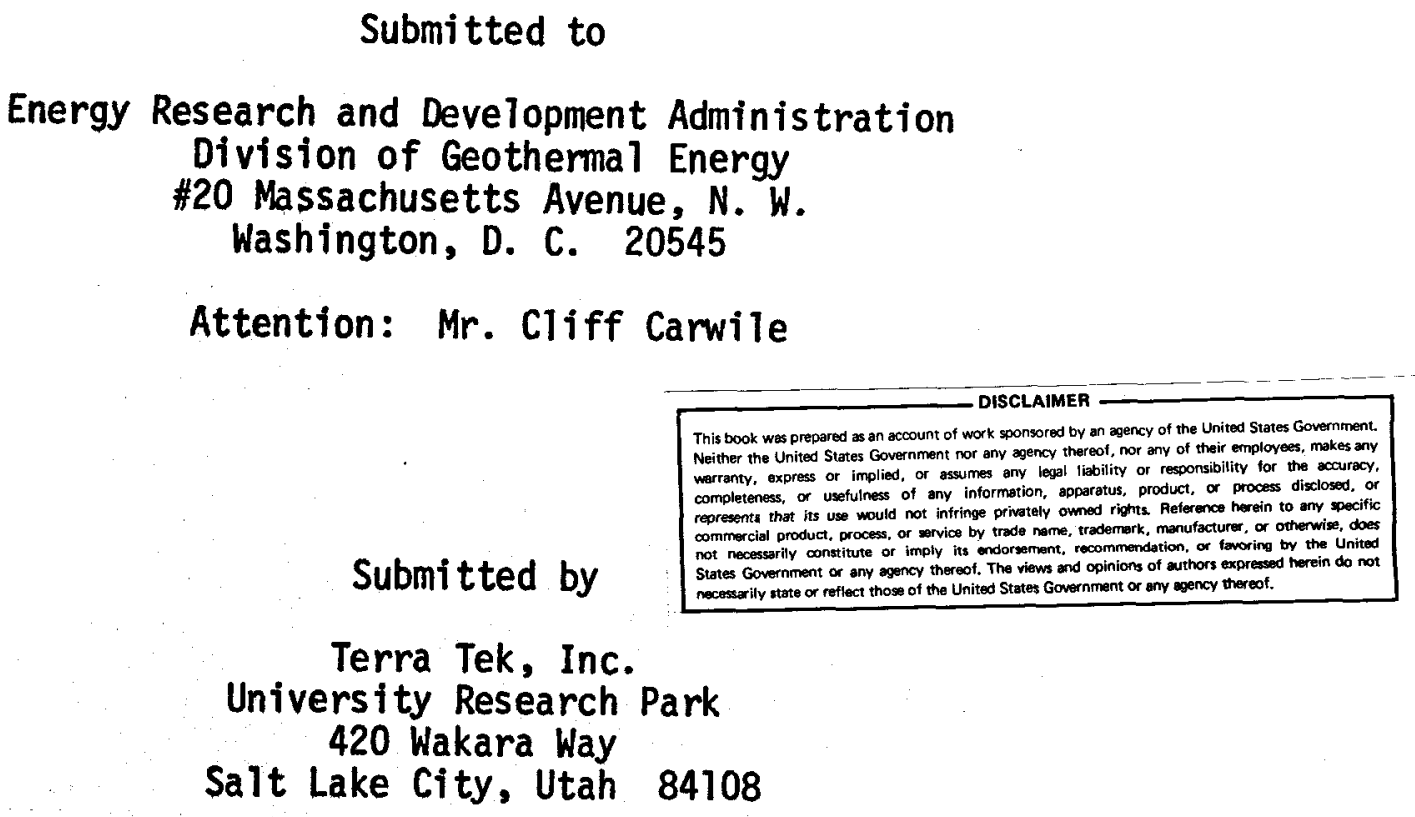

TR 76-70

December 1976 


\section{DISCLAIMER}

This report was prepared as an account of work sponsored by an agency of the United States Government. Neither the United States Government nor any agency Thereof, nor any of their employees, makes any warranty, express or implied, or assumes any legal liability or responsibility for the accuracy, completeness, or usefulness of any information, apparatus, product, or process disclosed, or represents that its use would not infringe privately owned rights. Reference herein to any specific commercial product, process, or service by trade name, trademark, manufacturer, or otherwise does not necessarily constitute or imply its endorsement, recommendation, or favoring by the United States Government or any agency thereof. The views and opinions of authors expressed herein do not necessarily state or reflect those of the United States Government or any agency thereof. 


\section{DISCLAIMER}

Portions of this document may be illegible in electronic image products. Images are produced from the best available original document. 


\section{FOREWORD}

This report represents the semi-annual progress report for Phase II of ERDA Contract No. E(10-1)-1546, "To Design and Experimentally Test an Improved Geothermal Drill Bit." Work on Phase II of the contract was started May 19, 1976; this report summarizes the progress to November 19, 1976. 
This page intentionally left blank. 


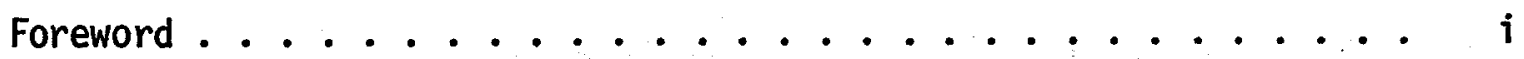

Table of Contents ........................ i i

List of Figures

List of Tables

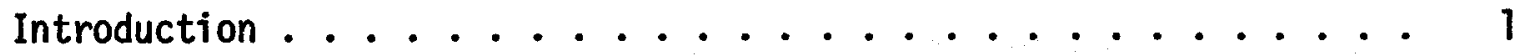

Task I - Unsealed Drill Bit .............. 3

Baseline Properties ................. 3

Geothermal Vessel ................ 5

Drill Bit Tests .................... 8

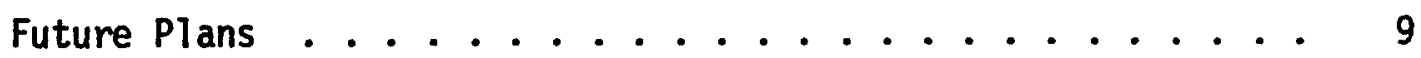

Task II - Elastomer Sealed Drill Bit . . . . . . . . . . 13

Task III - High Temperature Sealed Drill Bit . . . . . . . . 19

Task IV - Drill-Bit Insert Retention . . . . . . . . . 21

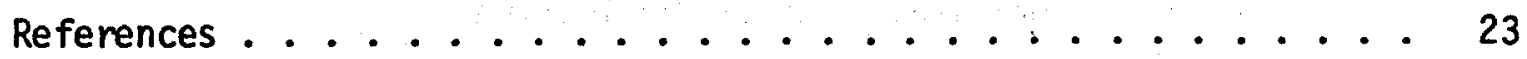

Appendix A - Bi-Monthly Progress Letters . . . . . . . . . Al

Appendix B - Fifth Program Discussion Meeting for the

Geothermal Drill Bit Program ...:......... B

\section{List of Figures}

Figure

Number

Description Page

1 Short rod specimen configuration ........... 4

$2 \quad$ Fracture toughness of drill-bit steels to $427^{\circ} \mathrm{C} \ldots \ldots$

3 Geothermal drilling test vessel ........... 14

$4 \quad$ Research drill bit and disassembled lug and cone from another research bit .......... 10 


\section{List of Figures}

Figure

Number

5

First research drill-bit cutter cone after first test.......................

Page

10

6 Friction pin region of second research bit after 2 hour test at $90 \mathrm{KN}(20,000 \mathrm{lb})$ thrust ....... 10

7 : A drawing of the seal test vessel . . . . . . . 16

8 A photo of the seal test facility . . . . . . . 17

9 A photo of the failed fluorosilicone seal . . . . . 17

10 Elastomer and stainless steel wire mesh composite seal . 20

11 The Schumacher face seal . . . . . . . . . . 20

12 Bellows face seal ................ . . . 20

\section{List of Tables}

Table

Number

I

Measurement of Dril1-Bit Wear After Testing at $316^{\circ} \mathrm{C}\left(600^{\circ} \mathrm{F}\right)$.................................. 11

II High-Temperature Elastomer Seal Materials . . . . . . . 14

III 


\section{INTRODUCTION}

Work began on an effort to design and test an improved geothermal drill bit [ERDA Contract No. E(10-1)-1546] on May 19, 1975. Phase I of the contract, which lasted for one year, was devoted largely to (1) the study of the geothermal environment and the failure mechanisms of existing geothermal drill bits, (2) the design and construction of test facilities for testing both drill-bit seals and full-scale drill bits under simulated geothermal drilling conditions, and (3) the procurement of research drill bits of high-temperature steels for the initial testing in the geothermal drill-bit test facility. The work accomplished in Phase $I$ is reported in References 1 through 8.

The present semi-annual report describes the progress made during the first half of Phase II of the program, covering the period from May 19 to November 19, 1976. Some of this work has already been described in two bi-monthly progress letters which are included as Appendix A.

During the period of this report, the test facilities (the geothermal drilling vessel and the geothermal drill-bit seal tester) were completed and "de-bugged", and the first tests were run on full-scale research drill bits and drill-bit seals. In addition, more materials information was gathered, and a number of additional seals of high-temperature elastomer materials were obtained for testing. Maurer Engineering, on a subcontract basis, has also been active in the design and procurement of candidate high-temperature drill-bit seals for testing, and has done a literature and patent search on the problem of drill-bit insert retention. Reed Tool Co. has cooperated in the fabrication of drill bits for testing, and has offered consultation on certain seal designs. 
The progress on each of the tasks of Phase II is presented in more detail on the following pages. 
The study conducted in Phase I on unsealed drill bits from the Geysers area showed that the drill bit failure modes are both bearing wear and gage wear.* However, the two types of wear can be related since either one can cause the other. Thus, although the basic problem may involve both bearing wear and gage wear, it is quite possible that either bearing wear or gage wear, but not both, is the major problem.

The Phase I study indicated that bearing wear is the primary source of unsealed drill bit failure because:

1. The drill-bit bearing races, and the ball and roller bearings themselves decrease appreciably in hardness at temperatures of $260^{\circ} \mathrm{C}$ and above at which these drill bits operated.

2. It is well known that bearing wear rates increase rapidly with decreasing bearing hardness.

3. The bearing wear on the bits examined was more consistent than the gage wear. The gage wear depended on the pattern of the bearing wear, i.e., on whether the wear at the friction pin was more or less than the wear on the roller race. In one case there was zero gage wear.

For these reasons attention has been focused on improving the hot hardness of the steels used in the drill bit, with the expectation that the gage wear problem will also be mitigated by improving the bearing life.

\section{Baseline Properties}

The full-scale drill bit test results must be correlated with certain baseline material properties to provide a better understanding of the test

* Gage wear is wear of the periphery of the drill bit, causing it to drill an under-size hole. 
results and to guide the selection of steels for additional research bits to be :tes.ted. The most pertinent material properties are the hardness, yield strength, elongation, fracture toughness, and thermal expansion, each as a function of temperature. Except for the fracture toughness, these properties were all collected from the literature or measured at Terra Tek for standard drill-bit steels and for the steels used in the first research drill bits procured during Phase I. No fracture toughness data were available for the steels of interest, however, and the fracture toughness therefore had to be measured. These measurements were carried out during the period of this report using the short rod technique 9,10 developed recently at Terra Tek. It is doubtful whether the standard ASTM tests could have measured the fracture toughness of the bearing steels because of their brittleness. The short rod technique is applicable to both brittle and ductile materials, and the specimen configuration (Figure 1) was particularly well adapted to the tests of the two drill-bit bearing steels, inasmuch as the specimens could be made from actual drill-bit roller bearings.

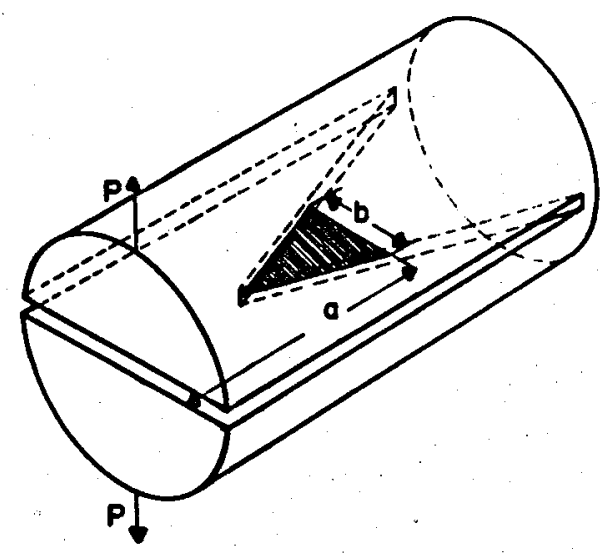

Figure 1. Short rod specimen configuration. The shaded area denotes the crack. 
The fracture toughness test results are shown in figure 2 , in which all of the data represent valid measurements except for the AISI 8620 data points. These are erroneous because the high temperature toughness and lower yield strength of the material dictate a larger sample size than used in these tests for valid measurements. Room temperature measurements on some larger samples of AISI 8620 indicate a fracture toughness of at least $100 \mathrm{MPa} \sqrt{\mathrm{m}}$, and the toughness may increase with temperature.

The fracture toughness values of the high temperature research drill bit steels are considerably smaller than the fracture toughnesses of the conventional drill bit steels (Figure 2). Since the toughness values of the research bit steels increase significantly with increasing temperature, higher temperature tests of the research bits are less severe than lower temperature tests as far as fracture is concerned. The fracture toughness measurements of the research bit steels and the Solar Steel are reported in a paper ${ }^{11}$ to be presented at the Fourth International Conference on Fracture to be held in Waterloo, Canada, in June, 1977. This paper is included as Attachment 1 of the present report.

\section{Geothermal Vessel}

A pressure-temperature vessel has been designed and constructed in which tests of full-scale research drill bits can be made under simulated geothermal drilling conditions. The vessel is capable of pressures to $35 \mathrm{MPa}$ (5000 psi) and temperatures to $427^{\circ} \mathrm{C}\left(800^{\circ} \mathrm{F}\right)$. The drill bit bearing wear is tested in the vessel by drilling against a mild steel drill pad at full-scale drill bit thrust forces. Figure 3 shows a drawing of the geothermal vessel. 


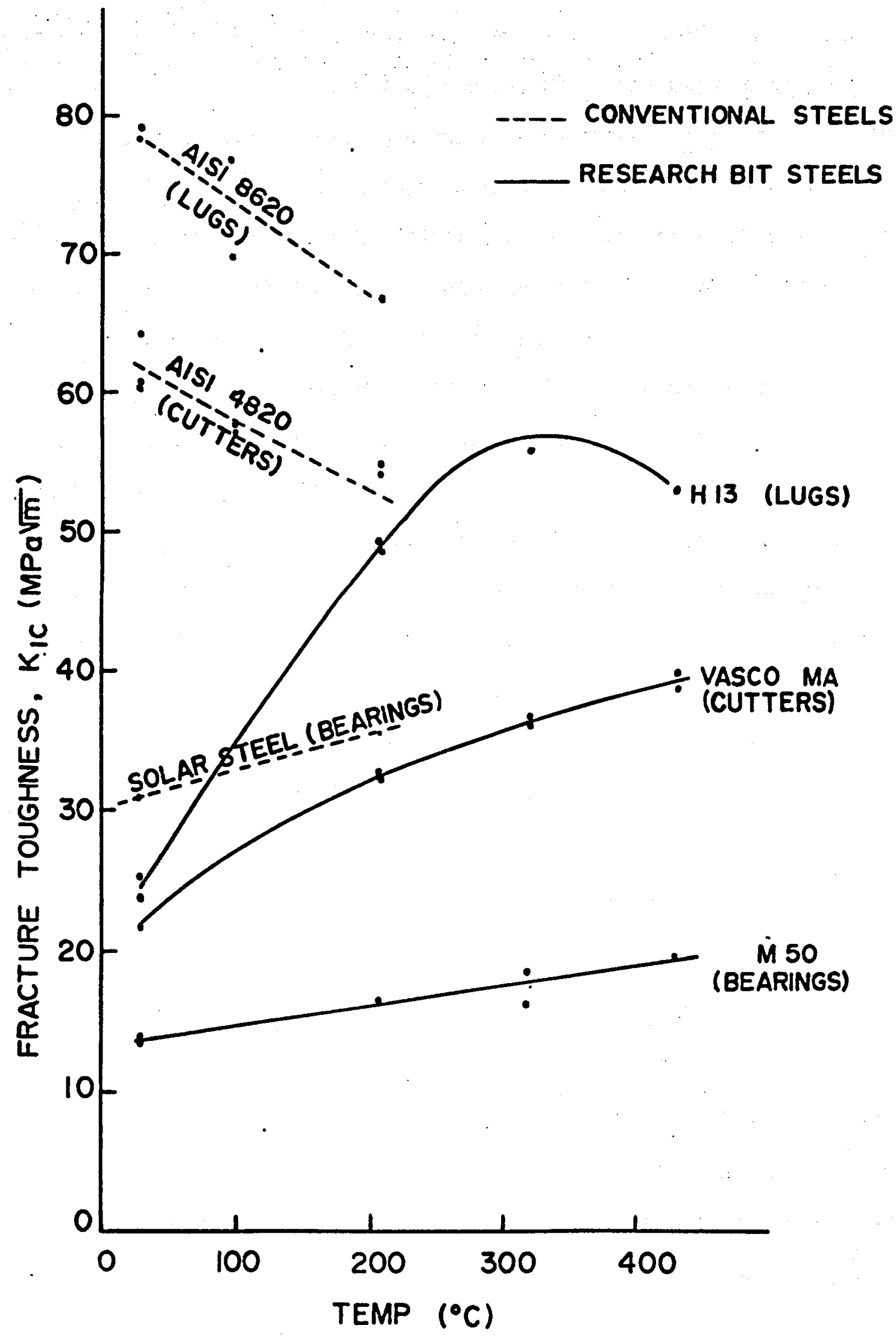

Figure 2. Fracture toughness of dri11-bit steels to $427^{\circ} \mathrm{C}$. All data points are valid except those of AISI 8620 , which are significantly lower than the actual fracture toughness (see text). 


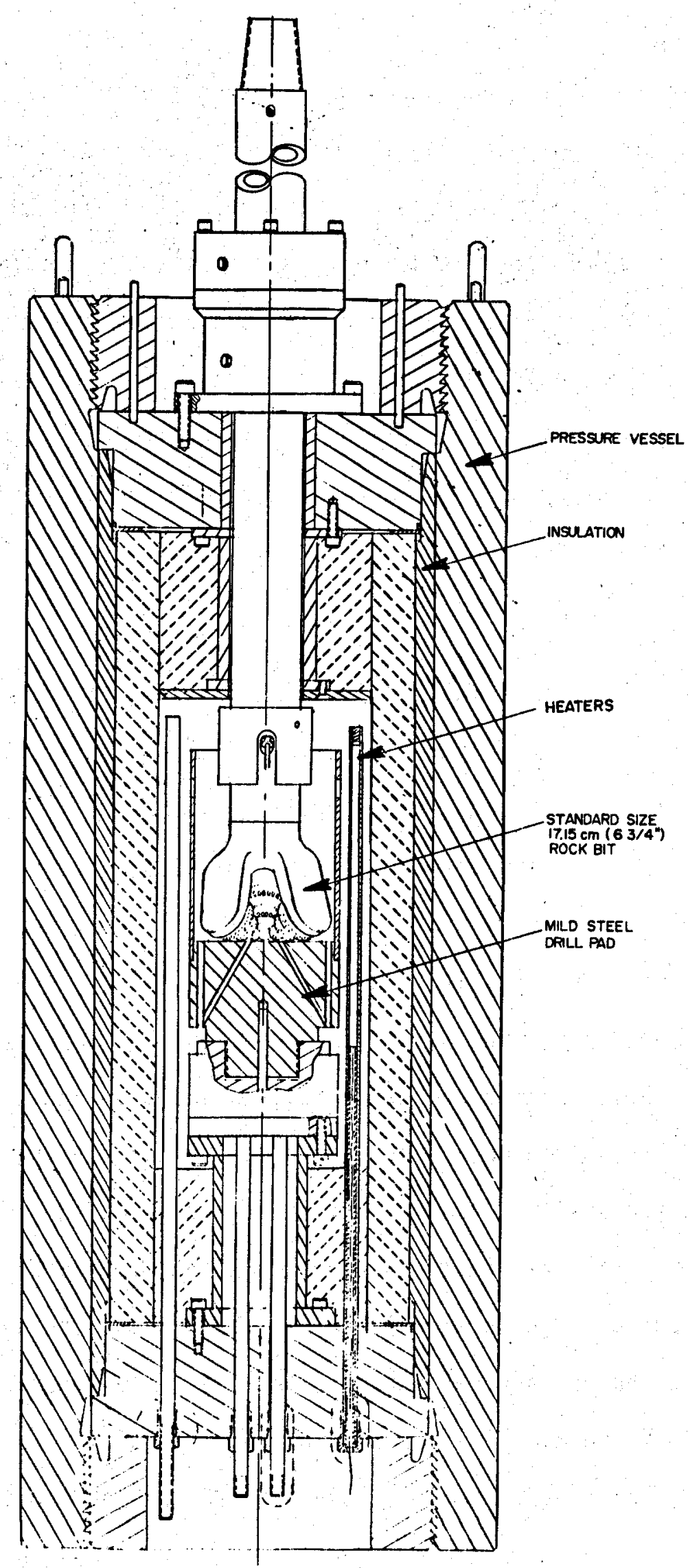

Figure 3. Geothermal drilling test vessel. The vessel is about $2 \mathrm{~m}$ tall. 
Considerable effort has been devoted to the completion and debugging of the geothermal vessel during the past half year. The problem of sealing the rotating shaft in the vessel with an internal temperature of $316^{\circ} \mathrm{C}$ $\left(600^{\circ} \mathrm{F}\right)$ proved particularly challenging. Solutions to this and other problems have been obtained, however, and the vessel currently operates reliably. The entire full-scale drill bit test facility performed admirally during the initial tests of research bits and standard control bits, and now constitutes a valuable high temperature, high pressure facility for future testing.

\section{Drill Bit Tests}

The initial tests of full-scale research drill bits of high temperature steels was accomplished during the period of this report. In addition, identical tests were run on control drill bits made of standard drill-bit steels. Wear comparisons between the control bits and the research bits were then made to evaluate progress in obtaining longer bearing life by using high temperature drill-bit steels.

The research bits and the standard control bits were especially designed to enable them to be periodically dismantled and examined for wear, and then reassembled and subjected to further testing. Figure 4 shows a research drill bit and a portion of a dismantled research drill bit.

The first drill-bit test runs in the geothermal vessel were made for short times and at light drill-bit thrust loads to assure examination of the drill bits before any catastrophic failure. The first research bit was tested for five minutes at a load of $22 \mathrm{KN}$ (5000 1b), a temperature of $316^{\circ} \mathrm{C}\left(600^{\circ} \mathrm{F}\right)$ and a hydrostatic pressure of $28 \mathrm{MPa}(4000 \mathrm{psi})$. During the test, the roller cones developed fractures between almost every adjacent 
pair of tungsten carbide inserts in the cones (Figure 5). The fracture pattern was dictated by the residual stresses due to pressing of the inserts, and the actual fracture resulted from the combination of these stresses and the stresses due to drilling. As a result of the failure of the research bit roller cone material, no further tests were conducted on the first research drill bit for fear of catastrophic failure of the roller cones.

The possibility of failure of the roller cone material had been foreseen. Therefore, the second research drill bit had been held at Reed Tool Co. pending a decision on the pressing of inserts. Since the inserts caused early failure of the first drill bit, the roller cones of the second drill bit were left without inserts. The drill bit was assembled and was run in the geothermal vessel with bare roller cones, thus avoiding the problem of roller cone fracture due to residual stresses from insert pressing. The second drill bit was also tested at $316^{\circ} \mathrm{C}$ and $28 \mathrm{MPa}$ for time periods and load levels which were gradually increased to two hours at $90 \mathrm{KN}(20,000 \mathrm{lb})$ plus an additional two hours at $110 \mathrm{KN}(25,000 \mathrm{lb})$ (full design bit load). The first control bit of conventional steel materials was then subjected to the identical test runs as the second research drill bit. Each test bit was disassembled and measured for bearing wear after each test run (Figure 6). Comparisons of total cumulative wear, along with hot hardness values, are shown in Table $I$. It is apparent that the control drill bit experienced 5 to 10 times as much wear as the research drill bit. This result seems to support the contention that bearing wear has been the principal cause of failure of geothermal drill bits.

\section{Future Plans}

The above test results were presented at the drill-bit guidance meeting 


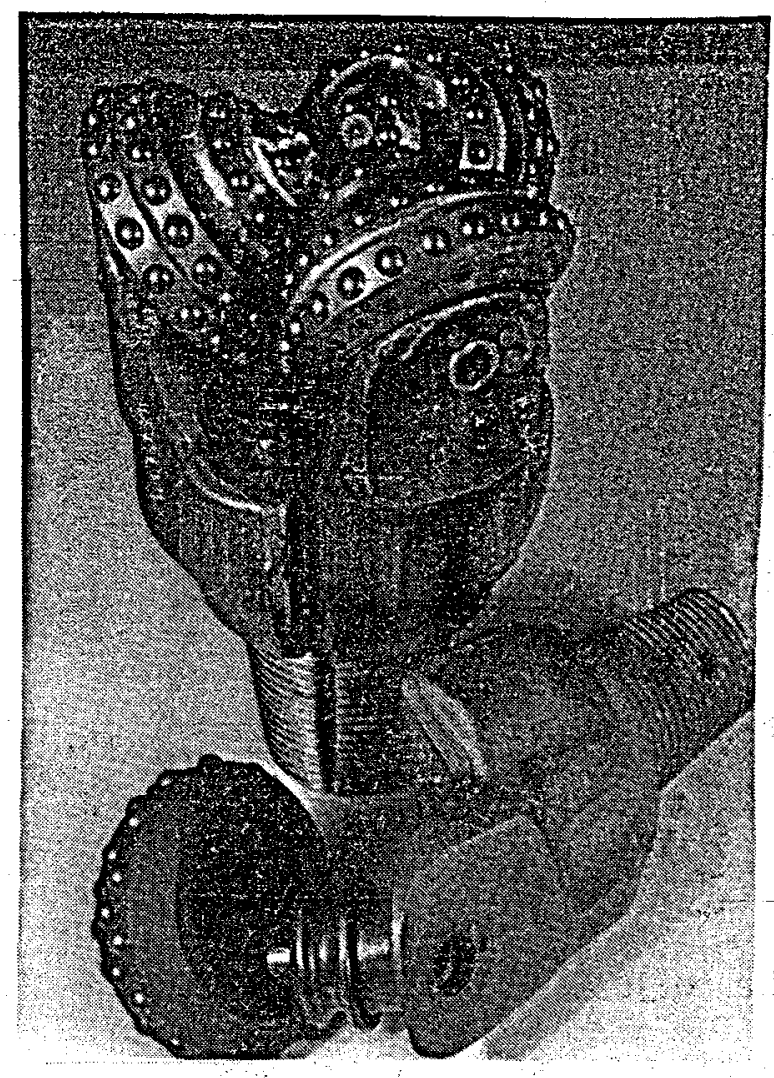

Figure 4. Reseârch dritl bit and disassembled lug and cone from another research bit. Special non-welded design allows bits to be taken apart to measure bearing wear, then reassembled for more testing.

Figure 5. First research drill-bit cutter cone after first test. Cracks can be seen between adjacent insert pairs:

Figure 6. Friction pin region of second research bit after 2 hour test at $90 \mathrm{KN}(20,000 \mathrm{lb})$ thrust. 
TABLE I

Measurements of Drill-Bit Wear After Testing at $316^{\circ} \mathrm{C}\left(600^{\circ} \mathrm{F}\right)$.

Each bit was subjected to a 2 hour test at

$90 \mathrm{KN}(20,000 \mathrm{1b})$ bit weight, plus an additional

2 hour test at $110 \mathrm{KN}(25,000 \mathrm{lb})$ bit weight.

\begin{tabular}{|c|c|c|c|}
\hline & & \multirow[b]{2}{*}{$\begin{array}{c}\text { Conventional } \\
\text { Bit }\end{array}$} & \multirow[b]{2}{*}{$\begin{array}{l}\text { Research } \\
\text { Bit }\end{array}$} \\
\hline & & & \\
\hline Ball Bearings & $\begin{array}{l}R_{c} \text { Hardness at } 316^{\circ} \mathrm{C} \\
\text { Wear }(\mathrm{mm})\end{array}$ & $\begin{array}{l}47 \\
.240\end{array}$ & $\begin{array}{l}59 \\
.025\end{array}$ \\
\hline Roller Bearings & $\begin{array}{l}\mathrm{R}_{\mathrm{c}}^{\prime} \text { Hardness at } 316^{\circ} \mathrm{C} \\
\text { Wear }(\mathrm{mm})\end{array}$ & $\begin{array}{l}47 \\
.080\end{array}$ & $\begin{array}{r}59 \\
.005\end{array}$ \\
\hline Cutter Roller Race & $\begin{array}{l}R_{c} \text { Hardness at } 316^{\circ} \mathrm{C} \\
\text { Wear }(\mathrm{mm})\end{array}$ & $\begin{array}{r}42 \\
.43\end{array}$ & $\begin{array}{l}56 \\
.06\end{array}$ \\
\hline Cutter Bushing & $\begin{array}{l}\mathrm{R}_{\mathrm{C}} \text { Hardness at } 316^{\circ} \mathrm{C} \\
\text { Wear }(\mathrm{mm})\end{array}$ & $\begin{array}{l}? \\
.08\end{array}$ & $\begin{array}{r}56 \\
0\end{array}$ \\
\hline Lug Roller Race & $\begin{array}{l}\mathrm{R}_{\mathrm{c}} \text { Hardness at } 316^{\circ} \mathrm{C} \\
\text { Wear }(\mathrm{mm})\end{array}$ & $\begin{array}{r}47 \\
1.09\end{array}$ & $\begin{array}{l}50+ \\
.22\end{array}$ \\
\hline Friction Pin & $\begin{array}{l}\mathrm{R}_{\mathrm{C}} \text { Hardness at } 316^{\circ} \mathrm{C} \\
\text { Wear }(\mathrm{mm})\end{array}$ & $\begin{array}{l}57 \\
?\end{array}$ & $\begin{array}{r}57 \\
.11\end{array}$ \\
\hline
\end{tabular}


held November 11, 1976 (Appendix B). At the meeting it was decided to test two more research bits made with a new roller cone material and a new ball and roller bearing material during the second half of Phase II. In addition, Reed Tool is to supply two standard drill bits for testing at different temperatures to determine the temperature limit at which standard drill bits can operate successfully. Also, Smith Tool Co. has been requested to supply two additional standard drill bits for testing of insert retention during high temperature drilling. These tests plus the tests of base line properties for the new roller cone and bearing materials will complete the Phase II effort on the unsealed drill bit. 


\section{TASK II - ELASTOMER SEALED DRILL BIT}

Drill bits can be further improved for geothermal applications by the development of sealing methods to allow the bits to operate at high temperatures with a lubricant sealed in the bearing area. 0il well experience indicates that bits with sealed and lubricated bearings last several times longer than unsealed bits. However, conventional drill-bit seals have maximum temperature limitations of about $175^{\circ} \mathrm{C}\left(350^{\circ} \mathrm{F}\right)$, and thus cannot be used in hot geothermal drilling environments. During the last half year (after a literature search and discussions with researchers and rubber producers), test seals made of a number of new high temperature elastomer materials have been obtained for testing. Table II enumerates the seal materials on hand together with some of the pertinent seal material properties.

In addition to testing high temperature seal materials, high temperature lubricants are of concern for the geothermal drill bit. It appears that good lubricants have temperature limitations comparable to those of elastomer seal materials. Table III lists a number of candidate lubricants which have been obtained for evaluation, together with some pertinent properties. The temperature limitations of the seal materials and lubricants listed in Tables II and III indicate that the elastomer-sealed drill bit temperature limitation will probably be in the range of 200 to $260^{\circ} \mathrm{C}\left(400\right.$ to $\left.500^{\circ} \mathrm{F}\right)$.

The seal test facility which was designed and partially fabricated during Phase I has now been completed (Figures 7 and 8 ). The first tests with the seal facility were made on seals of fluorosilicone and of ethylenepropylene elastomers. The fluorosilicone test at $200^{\circ} \mathrm{C}\left(400^{\circ} \mathrm{F}\right)$ was unsuccessful due to catastrophic failure of the seal (see Figure 9). A similar test was performed on the ethylene-propylene seal which appeared to survive the test, but nonetheless failed to prevent the lubricant from escaping from the sealed area. 
TABLE II

High-Temperature Elastomer Seal Materials

\begin{tabular}{|c|c|c|c|c|c|c|}
\hline $\begin{array}{c}\text { Product } \\
\text { Name }\end{array}$ & Producer & Material Class & $\begin{array}{l}\text { Probable } \\
\text { Temp Limit }\end{array}$ & Cost/Lb & $\begin{array}{c}\text { Potential } \\
\text { Compatability Problems }\end{array}$ & $\begin{array}{c}\text { Potential } \\
\text { Physical Properties } \\
\text { Problems }\end{array}$ \\
\hline Buna N (Nitrile) & At least 6 Co.'s & $\begin{array}{l}\text { Butadiene \& } \\
\text { acrylonitrile }\end{array}$ & $150^{\circ} \mathrm{C}\left(300^{\circ} \mathrm{F}\right)$ & Low & $\begin{array}{l}\text { High temp water and } \\
\text { steam }\end{array}$ & Low temp limit \\
\hline $\begin{array}{l}\text { Ethylene- } \\
\text { propylene }\end{array}$ & At least 5 Co.'s & Ethylene-propylene & $180^{\circ} \mathrm{C}\left(350^{\circ} \mathrm{F}\right)$ & Low & Petroleum base fluids & None \\
\hline Viton & Du Pont & Fluorocarbon & $260^{\circ} \mathrm{C}\left(500^{\circ} \mathrm{F}\right)$ & Low & $\begin{array}{l}\text { High temp water and } \\
\text { steam }\end{array}$ & Tear resistance \\
\hline Fluorosilicone & Dow Corning & Fluorosilfcone & $260^{\circ} \mathrm{C}\left(500^{\circ} \mathrm{F}\right)$ & Low & $\begin{array}{l}\text { Silicone lubes, water } \\
\text { and steam }\end{array}$ & $\begin{array}{l}\text { Tear \& abrasion } \\
\text { resistance; etc. }\end{array}$ \\
\hline PNF-200 & Firestone & $\begin{array}{l}\text { Phosphonitrilic } \\
\text { Fluoroelas tomer }\end{array}$ & $200^{\circ} \mathrm{C}\left(400^{\circ} \mathrm{F}\right)$ & $\$ 100$ & None expected & Unknown \\
\hline Kalrez & Du Pont & Perfluoroe las tomer & $260^{\circ} \mathrm{C}\left(500^{\circ} \mathrm{F}\right)$ & $\$ 2000$ & None & Unknown \\
\hline $5 A D-7004$ & $\begin{array}{l}\text { Custom Rubber } \\
\text { Products }\end{array}$ & Modified Buna $N$ & $230^{\circ} \mathrm{C}\left(450^{\circ} \mathrm{F}\right)$ & Low & None & Unknown \\
\hline
\end{tabular}


TABLE III

High-Temperature Lubricants

\begin{tabular}{|c|c|c|c|c|}
\hline Product Name & Producer & Material Class & $\begin{array}{l}\text { Probable } \\
\text { Temp Limit }\end{array}$ & Remarks \\
\hline $1200-2$ & Lubriplate & Petroleum grease & $230^{\circ} \mathrm{C}\left(450^{\circ} \mathrm{F}\right)$ & \\
\hline $930-\mathrm{AA}$ & Lubriplate & Petroleum grease & $200^{\circ} \mathrm{C}\left(400^{\circ} \mathrm{F}\right)$ & \\
\hline High Temp & Lubriplate & Petroleum grease & $260^{\circ} \mathrm{C}\left(500^{\circ} \mathrm{F}\right)$ & \\
\hline APG-90 & Lubriplate & Petroleum grease & $200^{\circ} \mathrm{C}\left(400^{\circ} \mathrm{F}\right)$ & \\
\hline$A F-419 C$ & Gulf & Silicone grease & $290^{\circ} \mathrm{C}\left(550^{\circ} \mathrm{F}\right)$ & $\begin{array}{l}\text { Poor load capability; poor } \\
\text { response to additives. }\end{array}$ \\
\hline LS- 1850 & $\begin{array}{l}\text { Graphite } \\
\text { Products }\end{array}$ & Anti-seize compound & $260^{\circ} \mathrm{C}\left(500^{\circ} \mathrm{F}\right)$ & $\begin{array}{l}\text { Contains } \mathrm{MoS}_{2} \text {. May go to } \\
430^{\circ} \mathrm{C}\left(800^{\circ} \mathrm{F}\right) \text {. } 0 \text { i1 base. }\end{array}$ \\
\hline Molykote $710 G$ & Dow Corning & $\begin{array}{l}\text { Silicone oil \& } \\
5 \% \text { graphite }\end{array}$ & $260^{\circ} \mathrm{C}\left(500^{\circ} \mathrm{F}\right)$ & $\begin{array}{l}\text { May go to } 370^{\circ} \mathrm{C}\left(700^{\circ} \mathrm{F}\right) \text {; } \\
\text { may have poor load capability. }\end{array}$ \\
\hline $\begin{array}{l}\text { Dow Corning } \\
44 \text { Grease }\end{array}$ & Dow Corning & Silicone grease & $200^{\circ} \mathrm{C}\left(400^{\circ} \mathrm{F}\right)$ & $\begin{array}{l}\text { Poor load capability; poor } \\
\text { response to additives. }\end{array}$ \\
\hline Molykote $321 R$ & Dow Corning & $\begin{array}{l}\text { Dry lubricating } \\
\text { film }\end{array}$ & $430^{\circ} \mathrm{C}\left(800^{\circ} \mathrm{F}\right)$ & High coef. of friction (0.1). \\
\hline SS-21 & $\begin{array}{l}\text { 0il Center } \\
\text { Research }\end{array}$ & $\begin{array}{l}\text { Teflon base dry } \\
\text { lubricating film }\end{array}$ & $290^{\circ} \mathrm{C}\left(550^{\circ} \mathrm{F}\right)$ & Poor load capability. \\
\hline
\end{tabular}


Following some minor modifications of the seal test facility, an extensive period of testing of elastomer seal materials is contemplated for the remainder of Phase II.

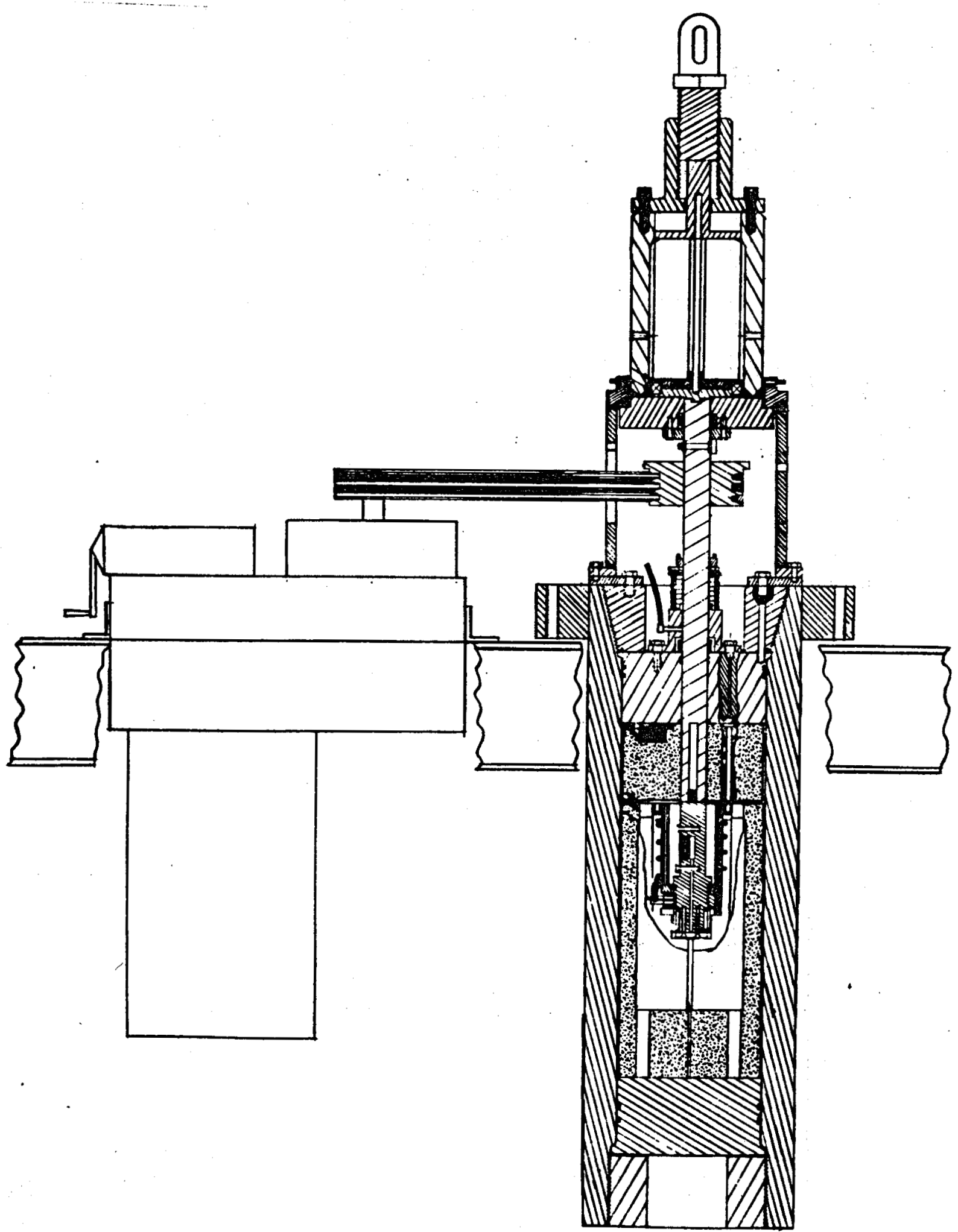

Figure 7. A drawing of the seal test vessel. 


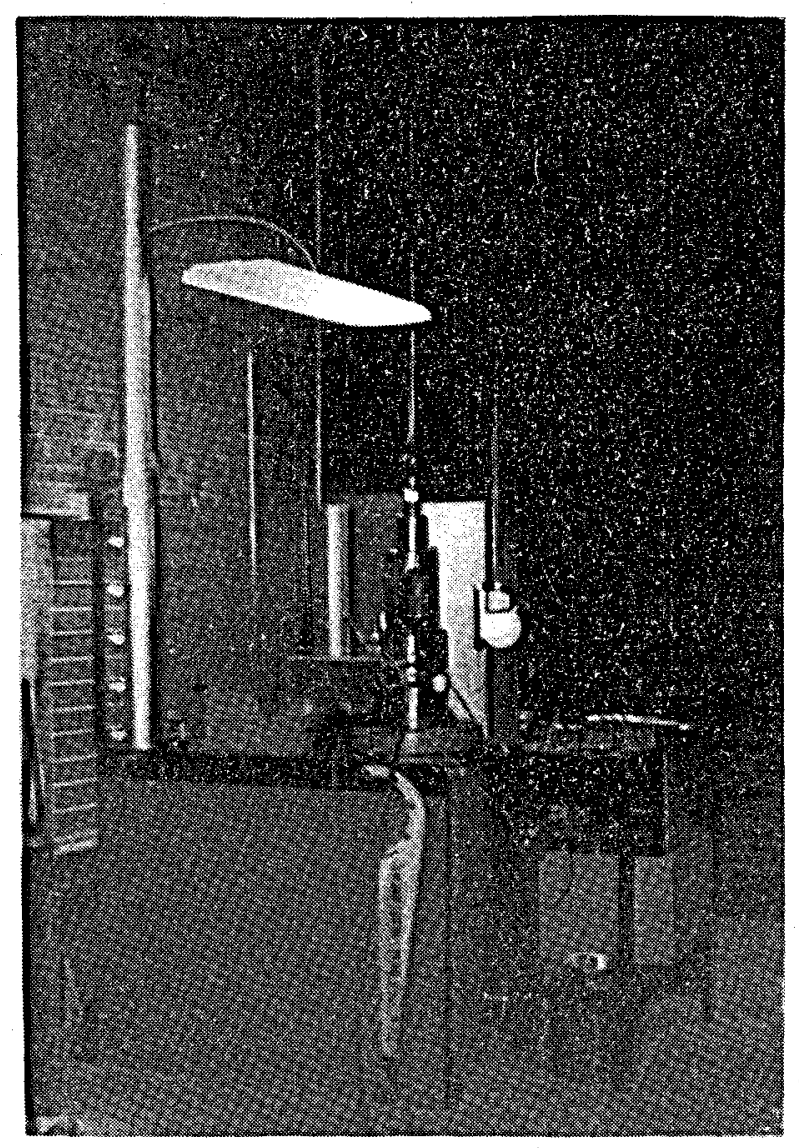

Figure 8. A photo of the seal test facility.

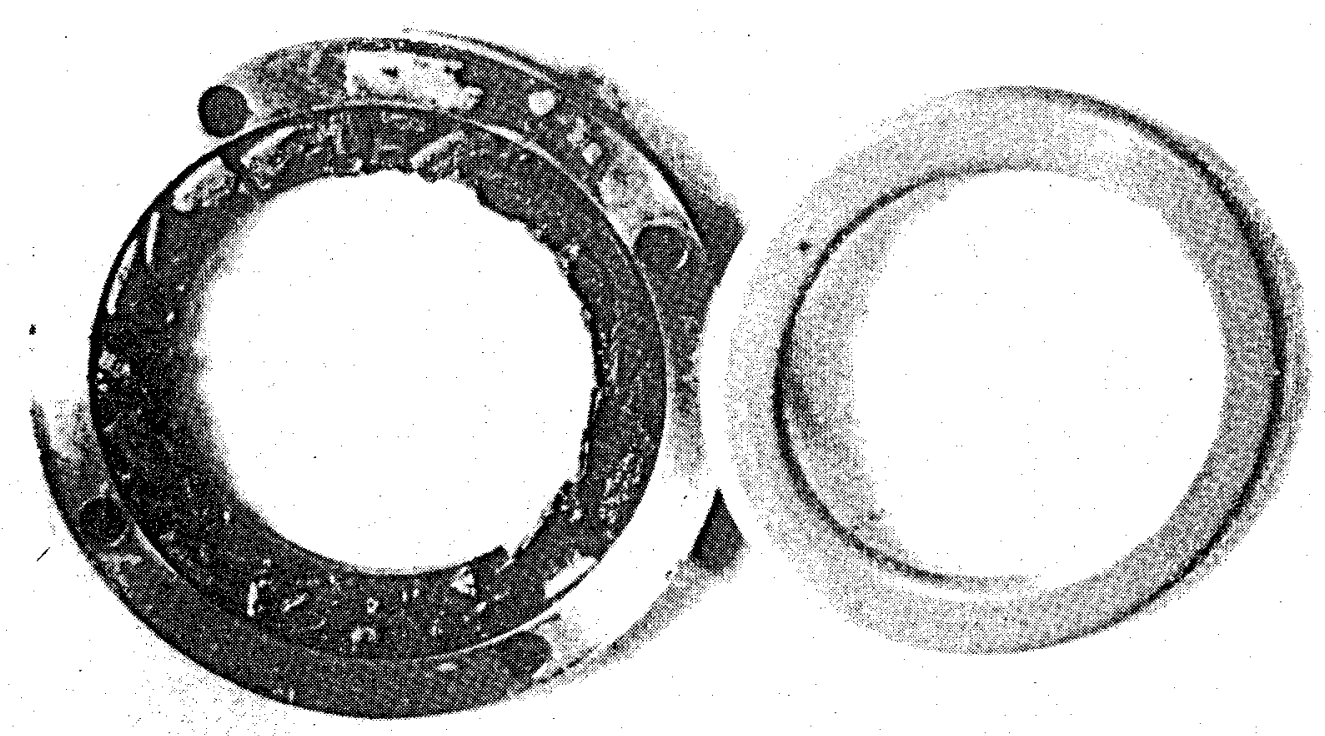

Figure 9. A photo of the failed fluorosilicone seal. 
This page intentionally left blank. 
TASK III - HIGH TEMPERATURE SEALED DRILL BIT

Since it appears that elastomer materials for conventional seal designs may not be suitable for temperatures above 200 to $260^{\circ} \mathrm{C}\left(400\right.$ to $\left.500^{\circ} \mathrm{F}\right)$, an effort is being made to design and test new drill-bit seal concepts for service in the 260 to $430^{\circ} \mathrm{C}\left(500\right.$ to $\left.800^{\circ} \mathrm{F}\right)$ temperature range. Maurer Engineering is assisting Terra Tek on a subcontract basis in the design and procurement of candidate seals for the higher temperature environment. Figures 10,11 and 12 show three seal types which are being investigated. Twenty-seven seals of the type illustrated in Figure 10 are being procured, each seal containing a different design and/or elastomer material modification. In addition, five identical seals of the type shown in Figure 11 are being made. These seals will all be tested in the same seal test facility as used for the conventional elastomer seals. 

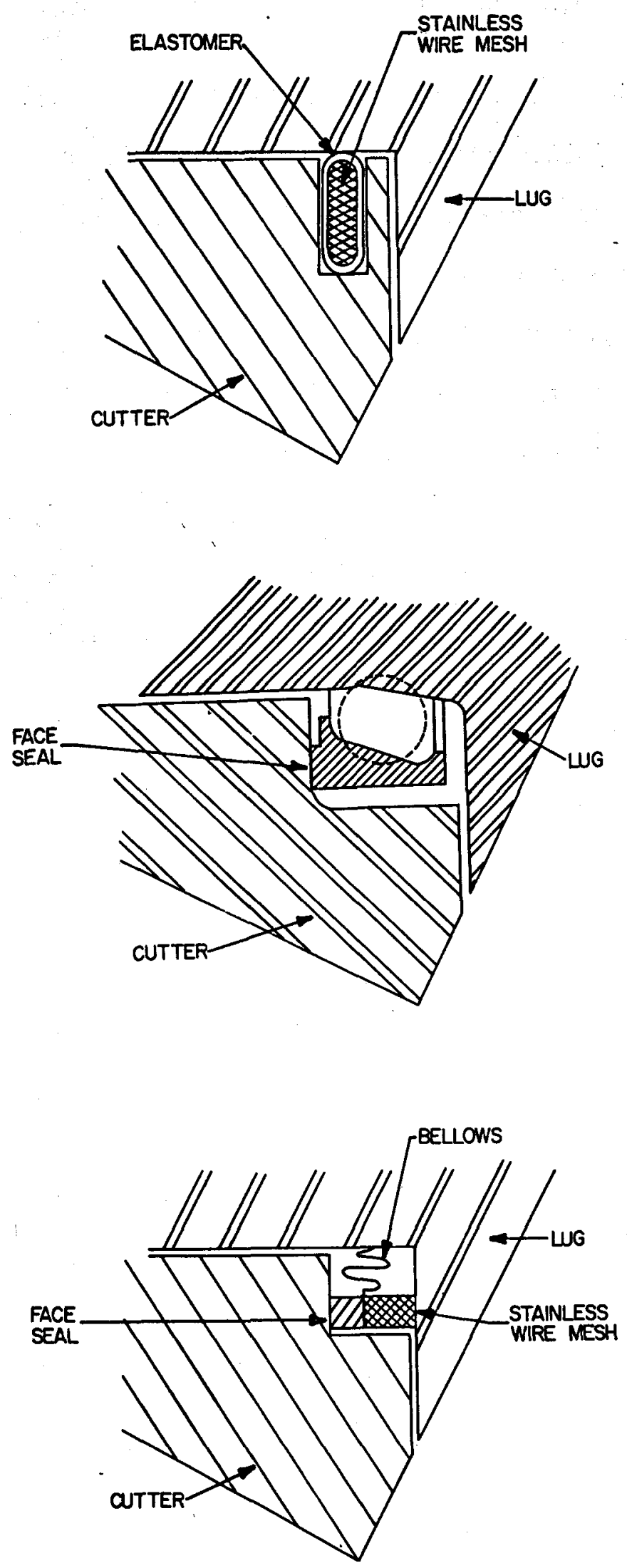

Figure 10. Elastomer and stainless steel wire mesh composite seal. The stainless wire mesh provides the required resilience at high temperature.
Figure 11. The Schumacher face seal. The " 0 " ring with the original cross section of the dashed circle is compressed in the space shown, causing the face seal of high temperature material to push against the mating surface on the cutter. The elastomer "0" ring is not subjected to sliding contact in this design.

Figure 12. Bellows face seal. The bellows is easily deformed in response to pressure fluctuations, thus minimizing transient pressure variations across the face seal. The stainless wire mesh acts as a spring to push the face seal against the mating surface on the cutter. No elastomers are used in this design. 


\section{TASK IV - DRILL-BIT INSERT RETENTION}

Because tungsten carbide inserts have much smaller thermal expansions than the steels in which they are held, there has been concern that the inserts may fall out of their holes when the temperature is increased. An extensive literature and patent survey has been conducted by Maurer Engineering regarding the insert retention problem, and results are currently being prepared in report form. In addition, Smith Tool Co. may provide two standard drill bits for study of the insert retention problem at high temperatures. Tests of these drill bits will be performed during the second half of Phase II.

As a result of the initial tests of the research drill bits and the failure of any inserts to work loose from the drill bit roller cones, it appears that the insert retention problem may not be as severe as formerly anticipated. Calculations involving actual insert pressing interferences now indicate that the inserts will not loosen at the temperatures anticipated in geothermal drilling, provided that the pressing interferences are not significantly decreased. Insert loss at high temperature is probably controlled more by the softening of the drill-bit roller cone steel, allowing plastic deformation, and the consequent working loose of the inserts, than by the difference in thermal expansion of the insert material and the retaining steel material. Thus, following the Maurer Engineering report of the literature and patent survey, and following the tests of the Smith drill bits (if provided) for insert retention, no further effort on the insert retention problem may be required. 
This page intentionally left blank. 


\section{REFERENCES}

1. L. M. Barker, S. J. Green, and W. C. Maurer, "Semi-Annual Report on the Project to Design and Experimentally Test an Improved Geothermal Drill Bit," TR 76-3, Terra Tek, Inc., Salt Lake City, Utah (January 1976).

2. L. M. Barker, S. J. Green, W. C. Maurer, and L. K. DeVries, "Annual Report on the Project to Design and Experimentally Test an Improved Geothermal Drill Bit," TR 76-32, Terra Tek, Inc., Salt Lake City, Utah (June 1976).

3. W. C. Maurer, "Patent Search and Review on Roller-Bit Bearings, Seals and Lubrication Systems," TR 75-55, Maurer Engineering, Inc., Houston, Texas (October 1975).

4. W. J. McDonald, "Temperature Distribution in Circulating Mud Columns," TR 75-67, Maurer Engineering, Inc., Houston, Texas (December $11,1975)$.

5. H. R. Pratt and E. R. Simonson, "Geological Studies of Geothermal Reservoirs," TR 76-2, Terra Tek, Inc., Salt Lake City, Utah (January 1976).

6. W. C. Leslie, "Examination of Failed Drill Bit from Geysers Field," TR 76-29, Terra Tek, Inc., Salt Lake City, Utah (February 1976).

7. L. M. Barker, S. J. Green, A. H. Jones, and M. Skalka, "Geothermal Environment Effects on Drill Bit Life," presented at the 11 th Intersociety Energy Conversion Conference, Lake Tahoe, September, 1976; also TR 76-19, Terra Tek, Inc., Salt Lake City, Utah (April 1976).

8. W. J. McDonald, "Steady-State and Transient Wellbore Temperatures During Drilling," TR 76-11, Maurer Engineering, Inc., Houston, Texas (May 1976).

9. L. M. Barker, "A Simplified Method for Measuring Plane Strain Fracture Toughness," accepted for publication in Engineering Fracture Mechanics.

10. L. M. Barker, "Evaluation of a Simple Method for Measuring Fracture Toughness in Both Brittle and Ductile Materials;" in Proceedings of the Second International Conference on Mechanical Behavior of Materials (ICM-II), Boston, Mass., 16-20 August, 1976, p. 1547.

11. L. M. Barker, "Short Rod KIc Tests of Several Steels at Temperatures to $427^{\circ} \mathrm{C}$, to be presented at the Fourth International Conference on Fracture (ICF-4), Waterloo, Canada, June 19-24, 1977. 
This page intentionally left blank. 


\section{APPENDIX A}

\section{Bi-Monthly Progress Letters}


This page intentionally left blank. 
August 2, 1976

Mr. Cliff Carwile

Division of Geothermal Energy

Energy Research and Development

Administration

Washington, D. C. 20545

RE: Bi-monthly progress letter on the program to develop and test an improved geothermal drill bit, ERDA Contract E(10-1)-1546.

Dear Mr. Carwile:

The following is a brief description of Terra Tek's progress during the two months from May 19 to July 19, 1976, on the program to develop and test an improved geothermal drill bit.

1. The geothermal vessel in which the research drill bits will be tested at temperatures to $427^{\circ} \mathrm{C}\left(800^{\circ} \mathrm{F}\right)$ and pressures to $35 \mathrm{MPa}(5000$ psi) is nearing completion. The final stages of fabrication and assembly have been considerably more time-consuming than anticipated, but no serious difficulties are foreseen. We now expect to begin testing by August 15.

2. The first research drill bit delivered by Reed Tool Co. was examined in preparation for the initial tests. A spattering of stellite hard-facing material was found on the thrust face bearing surfaces of two of the three drill-bit lugs. The spattered stellite build-up was up to $0.25 \mathrm{~mm}(0.01 \mathrm{in}) \mathrm{high}$, and could have resulted in immediate excessive wear of the mating surface in the cutter cone, thus invalidating the test results. The two defective lugs were returned to Reed Tool, where the bearing surfaces were ground smooth. The finished drill bit is now ready for testing, and is believed to be free from defects except for a small crack in one of the three cutter cones between two of the gage row inserts.

3. Additional base-line material properties of the steels used in the standard and research drill bits have been measured. The base-line data are now complete except for fracture toughness values as a function of temperature. Fracture toughness samples have been prepared from the steels of interest, and fixtures for performing the tests at various temperatures have been designed and made. The fracture toughness tests will follow shortly. 
Mr. Cliff Carwile

August 2, 1976

Page two

4. The seal test facility is in the final stages of assembly, and the testing of seal materials and seal designs under realistically simulated geothermal drilling conditions will begin shortly. Two candidate seal materials are ready for testing, and others are being procured. Reed Tool Co. has completed some preliminary screening tests of fluorosilicone seals provided by Terra Tek. Reed's results show that fluorosilicone seals tolerate temperatures to at least $288^{\circ} \mathrm{C}\left(550^{\circ} \mathrm{F}\right)$ for one hour, but that their abrasion resistance appears unacceptable.

5. Additional information has been gathered concerning candidate lubricants for use at the elevated temperatures at which the new seals will be tested. As a general rule, the commercial lubricants which withstand the higher temperatures (above about $300^{\circ} \mathrm{C}$ ) have other disadvantages such as increased friction, which can lead to even higher temperatures. However, it does appear that good lubricants can be obtained for temperatures to about $260^{\circ} \mathrm{C}$, which is probably at least as high as the temperatures that can be tolerated by suitable elastomer seal materials. The lubricants for use with higher-temperature, non-elastomer seals may still present a problem.

6. Some preliminary work has been done by Maurer Engineering with regard to gathering references for the patent search on the insert retention problem.

It was a pleasure reviewing the program with you in some detail July 29 and 30 .

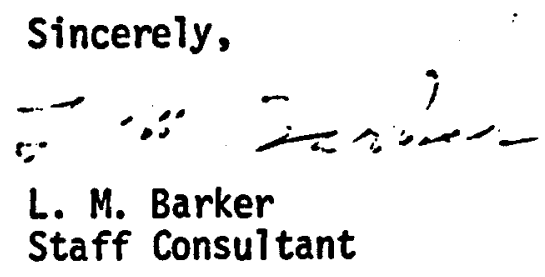

LMB/sf

cc: Mr. Dave Letendre

Mr. Bob Doyle

Mr. Dewey Thiessen

Dr. W. C. Maurer

Dr. L. DeVries

Dr. W. C. Lestie 


\section{TerraTek}

September 28, 1976

Mr. Cliff Carwile

Division of Geothermal Energy

Energy Research and Development

Administration

Washington, D. C. 20545

RE: Bi-monthly progress letter on the program to develop and test an improved geothermal drill bit, ERDA Contract E(10-1)-1546.

Dear Mr. Carwile:

The following is a brief description of Terra Tek's progress during the two months from July 19 to September 19, 1976, on the program to develop and test an improved geothermal drill bit.

Geothermal Drill Bit Test Vessel. A major effort has been devoted to the completion of the geothermal vessel in which research drill bits can be tested at temperatures to $427^{\circ} \mathrm{C}\left(800^{\circ} \mathrm{F}\right)$ and pressures to $35 \mathrm{MPa}$ (5000 psi). Problems were encountered in sealing the rotating drill stem which turns the drill bit inside the vessel. After several design iterations, the seal now lasts long enough for the first full-scale tests. Further design changes to extend the seal life are under way. Attaining the desired temperature was also a problem requiring attention, and although the target temperature for the first tests, $316^{\circ} \mathrm{C}\left(600^{\circ} \mathrm{F}\right)$, can now be attained, some further reduction of heat loss is planned in order to reach the maximum design temperature of $427^{\circ} \mathrm{C}\left(800^{\circ} \mathrm{F}\right)$.

Drill Bit Testing. The first test of a research drill bit in the simulated geothermal environment of the geothermal vessel has been conducted. is discussed and recommended at the geothermal drill bit program guidance meeting in Houstor, Texas last April, the first test was conducted in water at $316^{\circ} \mathrm{C}\left(600^{\circ} \mathrm{F}\right), 28 \mathrm{MPa}(4000 \mathrm{psi})$ pressure, $22 \mathrm{kN}(5000 \mathrm{lb})$ thrust, and 60 RPM for a period of 5 minutes. The Vasco MA steel of the drill bit cutter cones was badly cracked by the test, with most of the cracks running between adjacent tungsten carbide inserts. The crack pattern was apparently dictated by the residual stresses from press-fitting the inserts into the cutter cones, and resulted from the combination of residual stresses and drilling stresses. Except for the Vasco MA of the cutting cones, the research drill bit steels appear to have performed satisfactorily, with some corrosion but no measurable wear. This would certainly be expected from such a short, light-load test, hovever. 
These results have been communicated to Mr. P. W. Schumacher, Reed Tool, and to Dr. W. Leslie, University of Michigan. The concensus is that the failure of the Vasco MA is disappointing, but not entirely unexpected. The next iteration on drill bit steels will have to sacrifice some hot hardness for added toughness.

The tested drill bit will not be re-tested with its cracked cutter cones for fear the cones may break, resulting in damage to the inside of the geothermal vessel. Instead, the second research bit will be tested without any inserts pressed into the cutter cones. The second bit has been held at Reed Tool pending the decision on whether or not to press inserts into the cutters.

Base-Line Material Properties. An extensive series of fracture toughness tests has been performed to complete the base-line material properties data for the steels used in the standard and research drill bits. Tests were done on six different steels, all as functions of temperature from $24^{\circ} \mathrm{C}$ to $204^{\circ} \mathrm{C}$ (standard bit steels) or to $417^{\circ} \mathrm{C}$ (research bit steels). As far as could be determined, no fracture toughness measurements have ever been made on these steels. A new "short rod" method, recently developed at Terra Tek, was used to measure the critical stress intensity factors, $K$ (fracture toughness). Because of the brittleness and small sample size of the high-strength bearing steels tested, it was not possible to make the K measurements by conventional techniques. The short rod method is especially suited to brittle materials and small samples, and can test ductile materials as well.

As seen in Figure 1, the fracture toughness of the research bit steels increased substantially with increasing temperature; however, even at the higher temperatures, they reached only somewhat more than haif the lowtemperature toughness of the corresponding standard bit steels. This result helps explain the failure of the Vasco MA steel of the research bit cutter cone.

Seal Test Facility. Additional progress has been made on the geothermal seal test facility, which should be completed within the next month. As with the geothermal vessel, the final stages of fabrication and assembly have been more time-consuming than anticipated, but no serious difficulties are foreseen.

Seals. The ethylene-propylene seals which were obtained for the initial testing in the seal test facility were made too large, and the manufacturer has now supplied the correct size at no additional charge. Fluorosilicone seals are also on hand, and nitrile, Viton, and Firestone PNF-200 seals are on order. Seals from DuPont and Dow Corning high-temperature elastomers are in the procurement stage. In addition, Maurer Engineering, on a subcontract to Terra Tek, is working on several different high-temperature seal designs which will be evaluated in our seal tester. 
Mr. Cliff Carwile

September 28, 1976

Page three

Lubricants. A number of lubricants have been obtained for testing with the various seals in the seal test facility. These include products of Lubriplate (Fiske Brothers Refining Co.), Dow Corning, and Gulf Oil. Lubricants must be chosen not only for high temperature serviceability, but also for high load carrying capacity and for compatibility with the particular seal material.

Insert Retention. Maurer Engineering has gathered the patents pertaining to the insert retention problem, and is in the process of assembling the pertinent information in a topical report.

Sincerely,

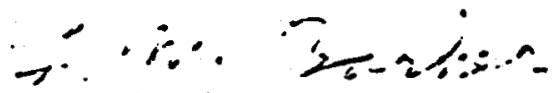

L. M. Barker

Staff Consultant

LMB/sf

Enclosure

cc: Mr. Dave Letendre

Mr.

Mr. Dewey Thiessen

Dr. W. C. Maurer

Dr. L. DeVries

Dr. W. C. Leslie 


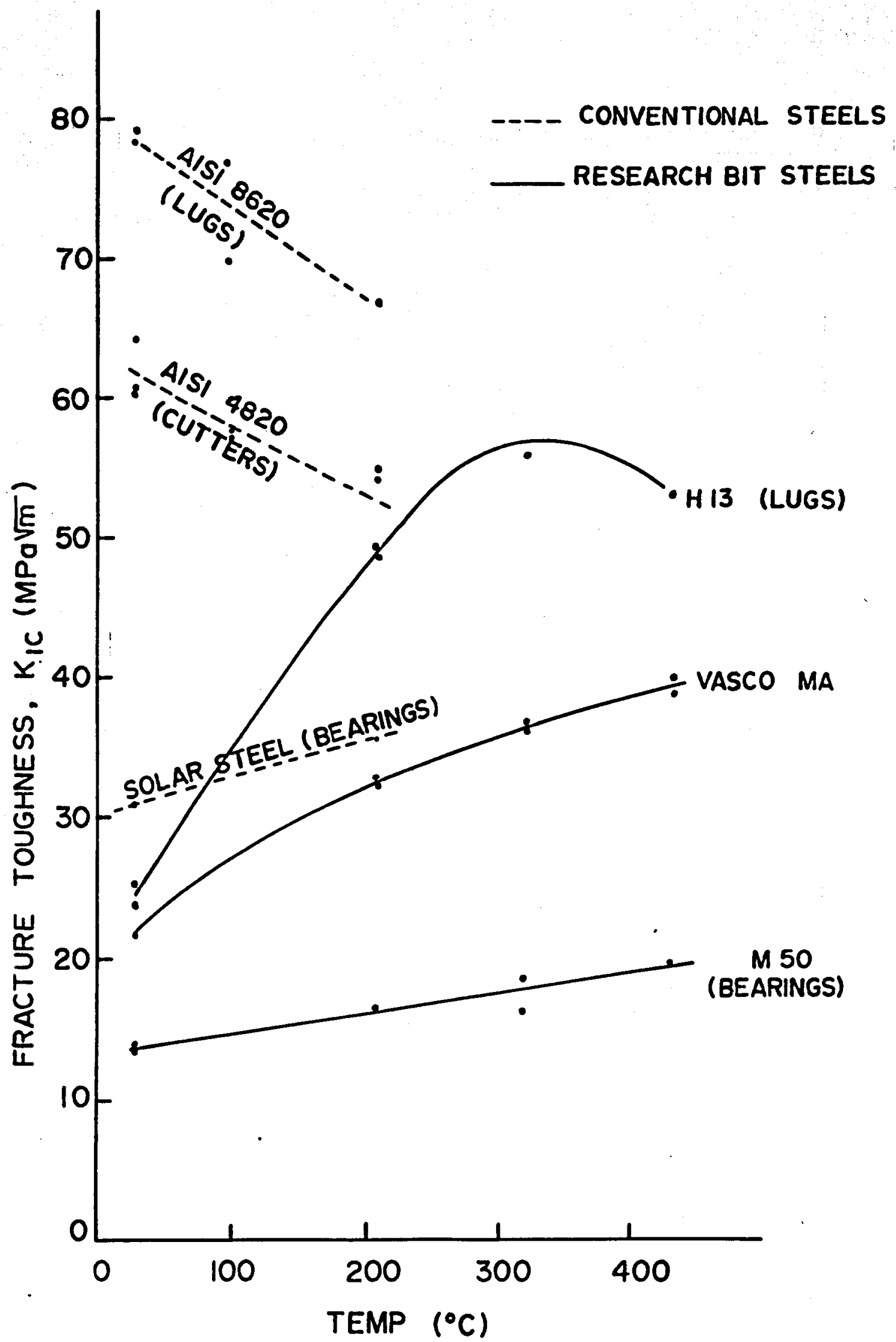

Figure 1. Fracture toughness vs, temperature of drill-bit steels. 


\section{APPENDIX B}

Fifth Program Discussion Meeting for the Geothermal Drill Bit Program 
This page intentionally left blank. 
TERRA TEK CONTRACT E(10-1)-1546

"DEVELOPMENT OF AN IMPROVED

GEOTHERMAL DRILL BIT"

Fifth Program Discussion Meeting for

the Geothermal Drill Bit Program

November 1.1, 1976

signed: $\frac{\text { Jymue M. Baske }}{\text { Lynn M. Barker }}$

TR 76-64

November 1976 
This page intentionally left blank. 
Fifth Program Discussion Meeting for the Geothermal Drill Bit Program

\section{ATTENDEES :}

Terra Tek

S. J. (sid) Green

A. H. (Arfon) Jones

L. M. (Lynn) Barker

A. D. (Alan) Black

R. R. (Bob) Hendrickson

R. R. (Randy) Nielsen

J. G. (Jim) Wilson

K. L. (Larry) DeVries, Consultant (University of Utah)

W. C. (Bill) Leslie, Consultant (University of Michigan)

Reed Tool Company

P. W. (Bi11) Schumacher
T. (Terry) Mayo

ERDA/Geothermal Division

C. (Cliff) Carwile

D. (Dan) Hoggan

\section{FOREWORD}

The Fifth Program Discussion Meeting was held in Salt Lake City at Terra Tek on November 11 and 12, 1976, in combination with a meeting on the Downhole Motor project at Terra Tek. Presentations were made concerning all facets of these two projects. This meeting followed discussions on the same topics at Maurer Engineering in Houston, Texas, on November 9. Those present at Maurer Engineering included Cliff Carwile, Sid Green, Bill Maurer, Jeddy Nixon, Bill McDonald and Larry Matson. The discussions at Maurer Engineering are not specifically included in the following. 
This page intentionally left blank. 
TOPICS COVERED

\section{Lubricants and Seals}

The high temperature elastomer candidate materials for drill bit seals which have been obtained for testing were enumerated and discussed (Table. I). Samples of the seals on hand were displayed. Similarly, high temperature lubricants were enumerated and discussed (Table II). It st111 appears that the practical upper temperature limit for effective lubricants and elastomer seals may be in the 400 to $500^{\circ} \mathrm{F}$ temperature range. Nevertheless, this may suffice for most current geothermal applications, and would be much better than the current 11 mitation of $300^{\circ} \mathrm{F}$ or less.

\section{Drill Bit Seal Test Facility}

The newly completed drill bit seal test facility was described by Bob Hendrickson, and the participants were given a tour of the facility. The results of two initial tests of seals with the facility were presented. During a discussion a realistic test program was suggested in which candidate seal materials would be soaked at high temperature and then tested dynamically at somewhat lower temperatures to simulate the initial high temperatures encountered in tripping, followed by the lower temperatures (due to circulation of the drilling mud) encountered during drilling.

\section{Lubricant and Seal Test Future Plans}

An extensive program of elastomer testing in the seal test facility is just beginning. In addition, a number of new seal designs involving higher temperature materials will be tested in the same facility. Maurer Engineering is alding in the design and procurement of high temperature seals for testing. A program of lubricant testing is contemplated for Phase 
III of the drill bit program, including the design and fabrication of a lubricant tester to simulate the drill bit lubricant environment.

\section{Geothermal Drill Bit Test Vessel}

The geothermal vessel and the solution of the vessel seal problem were described by Randy Nielsen. The group was given an inspection tour of the test vessel.

5. Full-Scale Bit Tests and Correlation with Base Line Data

The test conditions of each bit tested in the geothermal vessel were reviewed. The cutters of the first research bit had fractured after only 5 minutes testing at 5000 ib bit weight. The second research bit and one of the control bits were each subjected to a two hour test at $20,000 \mathrm{lb}$ bit weight plus an additional two hour test at 25,000 lb bit weight. The wear of the bearings and bearing races of these drill bits were then compared. The measurements of wear together with the Rockwell C hardness at $600^{\circ} \mathrm{F}$ of the components of interest are given in Table III. It can be seen that the wear of the conventional drill bit was 5 to 10 times as great as the wear on the research bit.

The results of fracture toughness measurements on the several drill bit steels were presented (Figure 1). The fracture toughness of the Vasco MA cutter cone material is considerably less than the fracture toughness of the standard cutter cone material. Since the Vasco MA fractured in the first research bit, Bill Leslie has suggested Vasco X-2 CVM steel has the follow-on material for new cutter cones. This steel has good high temperature properties, although not quite as hard as Vasco MA, and should be considerably tougher than Vasco MA. Samples of Vasco X-2 CVM and a modified low carbon version of X-2 CVM have been obtained for fracture 
toughness tests in the laboratory before the fabrication of the new drill bit cutter cones.

Considerable discussion was held of high temperature bearing materials to replace the $M 50$ bearing steel used in the research bits, since Reed Tool tests have indicated that the M50 as used in the research drill bits is too brittle to be used in drill bits in the field. For lack of a suttable alternative high temperature bearing steel, it was decided to use M50 tempered to a Rockwell C hardness of 59 instead of 64 to increase its toughness. These bearings will be obtained with the assistance of Bill Leslie for use in new research bits to be tested in a few months. The lugs of the new research bits will be the same as the lugs of the present research bits. One set of three lugs will come from the five-minute test bit in which the cutter cones fractured. The lugs from that test are essentially new and undamaged. Another set of lugs has been held at Reed Tool in the rough machined condition. This set will be heat treated and finish machined for construction of a second research bit with the new cutter and bearing materials. In addition, Reed Tool will provide two standard 6-3/4 inch M83 bits in December or January for testing in the geothermal vessel. These bits will be used to determine the temperature limit at which standard bits should operate successfully.

\section{Drill Bit Insert Retention}

Smith Tool Co. has agreed to supply two standard drill bits for our study of the insert retention problem during high-temperature drilling. However, considering all information available at the present time, it was the opinion of the participants that the insert retention problem for a geothermal drill bit is probably no more severe than the retention problem 
in conventional drill bits. It is anticipated that tests of the Smith bits will confirm this judgment. Therefore, following these tests and the completion of the insert retention literature survey being conducted by Maurer Engineering, no further action may be required on the insert retention problem.

7. ERDA Geothermal Drilling Projects

The ERDA Department of Geothermal Energy Drilling Technology Projects in FY 1977 were described by Cliff Carwile. Major areas of interest are in drilling hardware, drilling fluids, and data telemetry. The longer range geothermal drilling technology program was also described. 
TABLE I

High-Temperature Elastomer Seal Materials

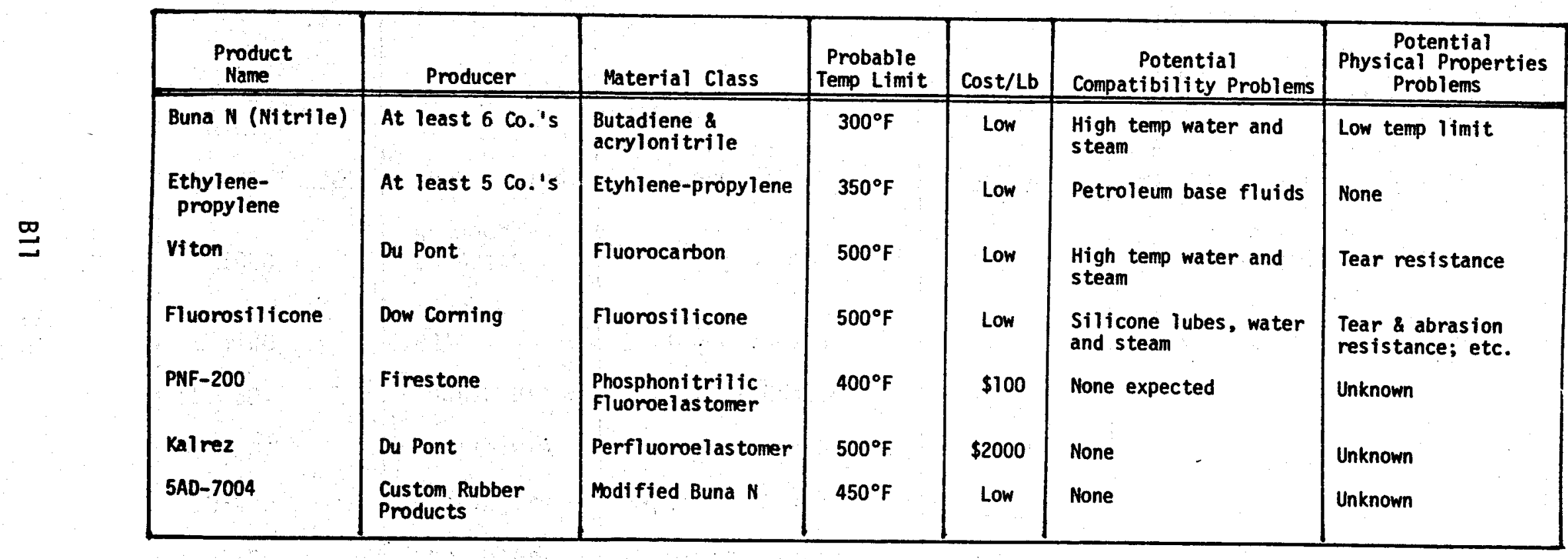


TABLE II

High-Temperature Lubricants

\begin{tabular}{|c|c|c|c|c|}
\hline Product Name & Producer & Material Class & $\begin{array}{l}\text { Probable } \\
\text { Temp Limit }\end{array}$ & Remarks \\
\hline $1200-2$ & Lubriplate & Petroleum grease & $450^{\circ} \mathrm{F}$ & \\
\hline $930-A A$ & Lubriplate & Petroleum grease & $400^{\circ} \mathrm{F}$ & \\
\hline High temp & Lubriplate & Petroleum grease & $500^{\circ} \mathrm{F}$ & \\
\hline APG-90 & Lubriplate & Petroleum grease & $400^{\circ} \mathrm{F}$ & \\
\hline AF-419C & Gulf & Silicone grease & $550^{\circ} \mathrm{F}$ & $\begin{array}{l}\text { Poor load capability; poor } \\
\text { response to additives }\end{array}$ \\
\hline LS-1850 & $\begin{array}{l}\text { Graphite } \\
\text { Products }\end{array}$ & Anti-seize compound & $500^{\circ} \mathrm{F}$ & $\begin{array}{l}\text { Contains } \mathrm{MoS}_{2} \text {. May go to } \\
800^{\circ} \mathrm{F} \text {. } 0 i 1 \text { base. }\end{array}$ \\
\hline Molykote $710 G$ & Dow Corning & $\begin{array}{l}\text { Silicone oil \& } \\
5 \% \text { graphite }\end{array}$ & $500^{\circ} \mathrm{F}$ & $\begin{array}{l}\text { May go to } 700^{\circ} \text {; may have } \\
\text { poor load capability }\end{array}$ \\
\hline $\begin{array}{l}\text { Dow Corning } \\
44 \text { Grease }\end{array}$ & Dow Corning & Silicone grease & $400^{\circ} \mathrm{F}$ & $\begin{array}{l}\text { Poor load capability; poor } \\
\text { response to additives }\end{array}$ \\
\hline Molykote $321 R$ & Dow Corning & $\begin{array}{l}\text { Dry lubricating } \\
\text { film }\end{array}$ & $800^{\circ} \mathrm{F}$ & High coef. of friction $(0.1)$ \\
\hline SS-21 & $\begin{array}{l}\text { 0il Center } \\
\text { Research }\end{array}$ & $\begin{array}{l}\text { Teflon base dry } \\
\text { lubricant }\end{array}$ & $550^{\circ} \mathrm{F}$ & Poor load capability \\
\hline
\end{tabular}




\section{TABLE III}

Measurements of Wear After Testing at $600^{\circ} \mathrm{F}$.

Each bit was subjected to a 2 hour test at $20,000 \mathrm{lb}$ bit weight, plus an additional 2 hour test at 25,000 ib bit weight.

\begin{tabular}{|c|c|c|c|}
\hline & & $\begin{array}{l}\text { CONVENTIONAL } \\
\text { BIT }\end{array}$ & $\begin{array}{l}\text { RESEARCH } \\
\text { BIT }\end{array}$ \\
\hline BALL BEARINGS & $\begin{array}{l}R_{C} \text { HARDNESS AT } 600^{\circ} \mathrm{F} \\
\text { WEAR (IN) }\end{array}$ & $\begin{array}{r}47 \\
.0094\end{array}$ & $\begin{array}{r}59 \\
.0010\end{array}$ \\
\hline ROLLER BEARINGS & $\begin{array}{l}R_{C} \text { HARDNESS AT } 600^{\circ} \mathrm{F} \\
\text { WEAR (IN) }\end{array}$ & $\begin{array}{r}47 \\
.0032\end{array}$ & $\begin{array}{r}59 \\
.0002\end{array}$ \\
\hline CUtTER ROLLER RACE & $\begin{array}{l}R_{C} \text { HARDNESS AT } 600^{\circ} \mathrm{F} \\
\text { WEAR (IN) }\end{array}$ & $\begin{array}{r}42 \\
.0186\end{array}$ & $\begin{array}{r}56 \\
.0024\end{array}$ \\
\hline CUtTER Bushing & $\begin{array}{l}R_{C} \text { HARDNESS AT } 600^{\circ} \mathrm{F} \\
\text { WEAR (IN) }\end{array}$ & $\begin{array}{c}? \\
.0032\end{array}$ & $\begin{array}{r}56 \\
0\end{array}$ \\
\hline LUG ROLLER RACE & $\begin{array}{l}R_{C} \text { HARDNESS AT } 600^{\circ} \mathrm{F} \\
\text { WEAR (IN) }\end{array}$ & $\begin{array}{r}47 \\
.0429\end{array}$ & $\begin{array}{r}50 t \\
.0086\end{array}$ \\
\hline FRICTION PIN & $\begin{array}{l}R_{C} \text { HARDNESS AT } 600^{\circ} \mathrm{F} \\
\text { WEAR (IN) }\end{array}$ & $\begin{array}{l}57 \\
?\end{array}$ & $\begin{array}{r}57 \\
.0042\end{array}$ \\
\hline
\end{tabular}




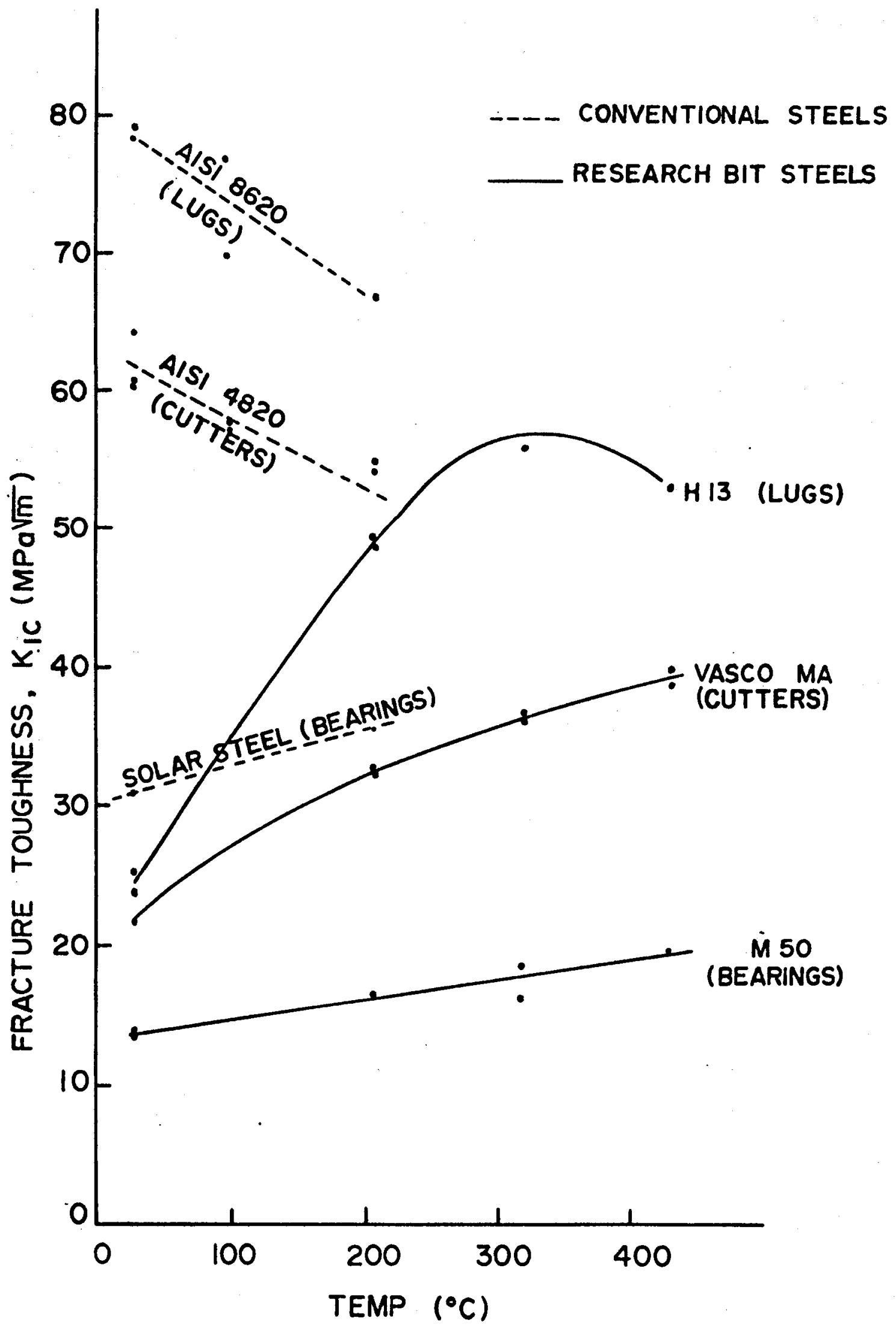

Figure 1. Fracture toughness vs. temperature of drill-bit steels. 